\title{
PENERAPAN METODE THINKING ALOUD PAIR PROBLEM SOLVING UNTUK MENINGKATKAN HASIL BELAJAR PESERTA DIDIK PADA MATERI DIMENSI TIGA DI KELAS XII MIPA 1 SMAN 8 BANDUNG
}

\author{
Yudin Wahyudin \\ SMAN 8 Bandung \\ yudin.wahyudin2@gmail.com
}

\begin{abstract}
ABSTRAK
Penelitian ini merupakan penelitian tindak kelas yang diimplementasikan kepada peserta didik kelas XII MIPA. Tujuan dilakukannya penelitian ini adalah untuk meningkatkan hasil belajar peserta didik dengan menggunakan metode Thinking Aloud Pair Problem Solving (TAPPS) pada pembelajaran dimensi tiga, yakni konsep jarak pada bangun ruang. Penelitian ini dilaksanakan dalam 2 siklus. Tiap siklus terdiri dari 4 tahap, yaitu perencanaan, pelaksanaan tindakan, observasi, dan evaluasi. Siklus I mencangkup materi konsep jarak titik ke titik, jarak titik ke garis, dan jarak titik ke bidang. Siklus II mencangkup materi konsep jarak garis ke garis, jarak garis ke bidang, dan jarak bidang ke bidang. Berdasarkan hasil penelitian diperoleh bahwa pada siklus I persentase ketuntasan peserta didik adalah 58\% dengan kategori cukup, pada siklus II persentase ketuntasan 70\% dengan kategori baik, dan pada ulangan harian presentasi ketuntasan mencapai $85 \%$ dengan kategori sangat baik. Maka dapat didimpulkan bahwa metode ini dapat digunakan untuk meningkatkan hasil belajar peserta didik.
\end{abstract}

Kata Kunci : Thinking Aloud Pair Problem Solving (TAPPS), Jarak, Bangun Ruang, Hasil Belajar.

\begin{abstract}
This research is a classroom action research that was implemented to students of the XII senior high school science program. The purpose of this research is to improve student learning outcomes by using the Thinking Aloud Pair Problem Solving (TAPPS) method in the learning of geometry material, the concept of distance in three-dimensional. This research was carried out in 2 cycles. Each cycle consists of 4 stages, there are planning, implementing actions, observing, and evaluating. In cycle I, we discuss about the concept of distance between two points, distance between points and line, and distance between point and plane. In cycle II, we discuss the concept of distance between two lines, distance between line and plane, and distance between two planes. Based on the results of the study, we found that the percentage of students' completeness in the first cycle was $58 \%$ with sufficient category, in the second cycle was $70 \%$ with good category, and in daily tests reached $85 \%$ with very good category. So, it was concluded that this method can be used to improve student learning outcomes.
\end{abstract}

Keywords : Thinking Aloud Pair Problem Solving (TAPPS), distance in three-dimensional, learning outcomes.

\section{PENDAHULUAN}

Pembelajaran merupakan proses untuk membantu peserta didik agar dapat belajar dengan baik. Pembelajaran akan bermakna bagi peserta didik apabila guru mampu memfasilitasi bagaimana cara belajar, berpikir, menyelesaikan masalah, serta mengambil keputusan. Dengan demikian, di dalam pembelajaran akan terjadi proses pemerolehan ilmu 
dan pengetahuan, penguasaan keterampilan, serta pembentukan sikap atau karakter yang baik pada peserta didik. Kenyataannya, di dalam pembelajaran di kelas, matematika masih dianggap sulit oleh sebagian peserta didik, salah satunya pada materi geometri. Sehingga, penelitian ini berfokus pada KD 3.1 dan 4.1 tentang materi dimensi tiga di kelas XII MIPA. Hal ini didasarkan pada rendahnya nilai ulangan harian siswa tahun 2016/2017 (rata-rata 71), maka diperlukan penelitian tindakan kelas yang dapat meningkatkan hasil belajar peserta didik pada materi ini.

Di dalam pembelajaran, guru memegang peran yang sangat penting. Artinya, guru sebagai tenaga profesional harus mampu memilih dan menentukan metode pembelajaran yang sesuai guna meningkatkan belajar peserta didik. Guru tidak hanya menjadi pemberi informasi, namun guru juga harus berperan sebagai fasilitator, motivator, dan pembimbing peserta didik agar dapat membantu peserta didik menggunakan semua hasil belajarnya untuk menyelesaikan suatu masalah. Bruffee menjelaskan bahwa pengajar tidak boleh hanya menjadi pemantau proses belajar namun pengajar juga harus mampu menjadi bagian dari pelajar yang tengah mencari pengetahuan (Barkley dan Major 2012). Oleh karena itu, dibutuhkan suatu pembelajaran yang diharapkan dapat mengembangkan hasil belajar peserta didik, suatu pembelajaran yang memberikan keleluasaan berpikir bagi peserta didik.

Dari sekian banyak pembelajaran yang ada, pembelajaran Kolaboratif diharapkan menjadi alternatif yang dapat digunakan untuk memperbaiki atau meningkatkan hasil belajar Matematika pada peserta didik. Pembelajaran kolaboratif dapat menghindarkan peserta didik dari ketergantungan terhadap guru, dimana guru adalah pemegang otoritas pada saat proses belajar berlangsung (Barkley dan Major 2012). Pembelajaran kolaboratif memudahkan para peserta didik belajar dan bekerja bersama, saling menyumbangkan pemikiran dan bertanggung jawab terhadap pencapaian hasil. Metode pembelajaran yang merupakan bagian dari Pembelajaran Kolabortif dan yang dianggap sesuai untuk meningkatkan hasil belajar adalah Metode pembelajaran Thinking Aloud Pair Problem Solving (TAPPS). Barkley dan Major (2012) mengungkapkan bahwa TAPPS dapat meningkatkan keterampilan peserta didik dalam memahami pemikiran mereka dan orang lain. Melalui metode TAPPS, peserta didik dapat dilatih untuk dapat berperan sebagai problem solver maupun listener.

Berdasarkan uraian di atas, maka peneliti tertarik untuk menerapkan metode TAPPS dalam pembelajaran materi dimensi tiga, terutama pada konsep jarak. Pembelajaran dengan 
menggunakan metode TAPPS diharapkan akan berdampak positif terhadap hasil belajar belajar peserta didik. Upaya tersebut dikaji di dalam penelitian tindakan kelas dengan judul "Penerapan Metode Thinking Aloud Pair Problem Solving untuk Meningkatkan Hasil Belajar Peserta Didik pada Materi Dimensi Tiga di Kelas XII MIPA 1 SMAN 8 Bandung”.

\section{Tujuan Penelitian}

Tujuan penelitian tindakan kelas ini adalah sebagai berikut:

1. Menerapkan metode Thinking Aloud Pair Problem Solving (TAPPS) pada pembelajaran dimensi tiga untuk peserta didik kelas XII MIPA 1 di SMAN 8 Bandung.

2. Meningkatkan hasil belajar peserta didik kelas XII MIPA 1 SMAN 8 Bandung dengan metode Thinking Aloud Pair Problem Solving (TAPPS) pada pembelajaran dimensi tiga.

\section{Kerangka Teoritis}

Berikut ini dijelaskan kerangka teoritis pada penelitian ini, diantaranya adalah kesulitan belajar, pemecahan masalah (problem solving), dan metode Thinking Aloud Pair Problem Solving (TAPPS).

\section{Kesulitan belajar}

Di dalam proses pembelajaran, tingkat kemampuan peserta didik berbeda. Beberapa pasti memiliki suatu kesulitan atau hambatan belajar terkait suatu materi pembelajaran. Hambatan belajar tersebut juga berbeda-beda, ada yang disebut hambatan ontigenik, hambatan didaktis, maupun hambatan epistimologis (Brousseau, 2002). Hambatan ontogenik adalah hambatan yang dialami peserta didik karena ketidaksiapan mental belajar. Hambatan didaktis adalah hambatan yang terjadi karena ketidaktepatan situasi atau metode pembelajaran. Sedangkan, hambatan epistimologis adalah hambatan yang terjadi akinat kesalahan atau kurangnya pengetahuan prasyarat ketika siswa hendak mempelajari pengetahuan baru. Kesulitan atau hambatan belajar ini dapat diminimalisir terjadi pada peserta didik jika guru mampu menerapkan metode belajar yang tepat.

\section{Pemecahan Masalah (Problem Solving)}

Masalah menurut Janulis P. Purba (2000) merupakan peristiwa yang harus kita ganti dengan suatu cara untuk mendapatkan apa yang kita inginkan. Masalah juga merupakan suatu keadaan terdapatnya kesenjangan antara apa yang terjadi dengan apa yang diinginkan atau dibutuhkan. Pemecahan masalah menurut Gagne (1977) adalah salah satu jenis belajar yang diperoleh secara bertahap melalui hierarki tingkat kompleksitas intelektual. Pemecahan 
masalah (problem solving) yaitu belajar menggunakan metode-metode ilmiah atau berpikir secara sistematis, logis, teratur dan teliti. Pemecahan masalah merupakan cara penyajian pembelajaran dengan menyajikan masalah sebagai titik tolak pembahasan untuk dianalisis dan disertai dalam usaha mencari pemecahannya. Pemecahan masalah juga merupakan suatu kegiatan manusia yang menggabungkan konsep-konsep dan aturan yang telah diperoleh sebelumnya dan tidak sebagai suatu keterampilan generik.

\section{Metode Thinking Aloud Pair Problem Solving (TAPPS)}

Metode Thinking Aloud Pair Problem Solving (TAPPS) dikembangkan oleh Arthur Whimbey, metode ini dapat membantu peserta didik di dalam penggunaan strategi pemecahan masalah (Crosss dan Major 2012). TAPPS adalah salah satu strategi untuk memecahkan masalah yang dilakukan secara kolaboratif terstruktur oleh beberapa orang peserta didik. Keuntungan dari penggunaan metode ini adalah melatih peserta didik memahami konsep, menghubungkan konsep yang telah ada dalam diri mereka dan menghasilkan pemahaman konsep yang mendalam.

Menurut Barkley, Crosss dan Major (2012 : 259), "Penyelesai masalah 'berpikir lisan', berbicara berdasarkan langkah-langkah. Mitranya mendengarkan dengan seksama apa yang disampaikan penyelesai masalah, mengikuti langkah-langkahnya, berusaha memahami penalaran dibalik langkah-langkah tersebut, dan memberi saran-saran jika langkah yang keliru".

Stice (1987) mengemukakan peran dari seorang problem solver di dalam pembelajaran dengan metode TAPPS adalah:

1. Membaca soal agar listener mengetahui permasalahan yang akan dipecahkan.

2. Mulai menyelesaikan soal dengan cara sendiri sambil menjelaskan kepada listener mengenai apa, mengapa dan bagaimana langkah tersebut diambil.

3. Problem solver harus berani dalam mengungkapkan segala hasil pemikirannya.

4. Mencoba untuk terus menyelesaikan masalah sekalipun masalah tersebut sulit.

Sedangkan peran listener adalah:

1. Memahami secara detail setiap langkah yang dilakukan problem solver.

2. Meminta problem solver untuk terus berbicara, tetapi tidak menginterupsi problem solver yang sedang berpikir.

3. Bertanya ketika problem solver mengatakan sesuatu yang kurang jelas. 
4. Listener tidak boleh membantu problem solver, jika ada kesalahan cukup tunjukkan kesalahannya tapi jangan dikoreksi.

Sedangkan peran guru di dalam kelas yaitu mengamati diantara pasangan peserta didik, memonitor aktivitas mereka dan memberikan perhatian khusus pada listener. Selain itu guru dapat berkeliling memonitor seluruh kelompok dan melatih listener mengajukan pertanyaan. Hal ini diperlukan karena keberhasilan model ini akan tercapai apabila listener berhasil membuat problem solver memberikan alasan dan menjelaskan apa yang mereka lakukan untuk memecahkan masalah. Jika terdapat kelompok yang mengalami kesulitan dalam memecahkan masalah tersebut maka guru dapat membantu kelompok tersebut dengan cara menjadi listener. Sehingga, jelas bahwa model ini mengedepankan peserta didik untuk dapat berpikir.

\section{METODE PENELITIAN}

Subjek pada penelitian ini adalah peserta didik kelas XII MIPA 1 SMA Negeri 8 bandung yang berjumlah 40 orang, Pada siklus I, setiap kelompok terdiri dari 2 orang berperan sebagai PS (Problem Solver) dan L (Listener) sedangkan pada siklus II setiap kelompok terdiri dari 2 orang, yang masing masing bertukar peran (PS menjadi L dan L menjadi PS).

Metode yang digunakan dalam penelitian ini adalah metode penelitian tindakan kelas yang dilakukan oleh guru dan sejawatnya di dalam pembelajaran yang bertujuan untuk memperbaiki pembelajaran sebelumnya. Penelitian tindakan kelas terdiri dari empat langkah utama pada setiap siklus yaitu rencana tindakan, pelaksanaan tindakan, pengamatan tindakan dan refleksi. Hasil refleksi dari siklus I akan digunakan dalam perencanaan pada siklus II.

Teknik dan alat pengumpulan data yang digunakan dalam penelitian tindakan kelas ini meliputi: a) pedoman observasi untuk mengecek kegiatan peserta didik dengan guru yang dilakukan berdasarkan indikator yang ditentukan sebelumnya dan b) lembar tes untuk melihat hasil belajar peserta didik.

Data hasil penelitian tindakan kelas ini akan dianalisis secara kualitatif dengan melihat persentase peningkatan hasil belajar peserta didik. Selanjutnya hasil analisis tersebut dilakukan tindakan lanjut. Data yang diperoleh dari hasil ulangan harian peserta didik akan digunakan untuk mengambil kesimpulan terhadap penelitian tindakan kelas. Indikator keberhasilan penelitian tindakan kelas terdiri dari: a) Peserta didik dapat menyelesaikan latihan soal-soal materi dimensi tiga, b) Kriteria ketuntasan minimal 75, dan b) Nilai hasil 
ulangan harian mengenai materi pembelajaran dimensi tiga diatas KKM dengan kategori sebagai berikut :

Tabel 1 Tabel Persentase Ketuntasan

\begin{tabular}{cc}
\hline Persentase Ketuntasan & Kategori \\
\hline $0 \%-20 \%$ & Sangat Kurang \\
$21 \%-40 \%$ & Kurang \\
$41 \%-60 \%$ & Cukup \\
$61 \%-80 \%$ & Baik \\
$81 \%-100 \%$ & Sangat Baik \\
\hline
\end{tabular}

\section{HASIL DAN PEMBAHASAN}

Data pada penelitian ini diperoleh dari lembar kerja, tes tulis, format observasi, pada setiap siklus yang dirancang berdasarkan pendekatan kooperatif tipe TAPPS (Thingking Aloud Pairs Problem Solver) pada pembelajaran peserta didik dikelompokkan 2 orang peserta didik mempunyai peran sebagai PS (Problem Solver) sedangkan yang lain sebagai L (listener) pada siklus I dan siklus II.

\section{Hasil Penelitian Serta Pembahasan Siklus I}

Pada pertemuan pertama, sebelum melakukan pembelajaran dengan menggunakan metode TAPPS, guru terlebih dahulu memberikan motivasi kepada peserta didik dalam bentuk pertanyaan sebagai prasyarat tentang materi dimensi tiga sub konsep jarak titik ke titik, jarak titik ke garis dan jarak titik ke bidang.

Supaya peserta didik dapat mengaplikasikan Dimensi Tiga, guru memberikan latihan soal yang dilakukan dengan berkelompok. Peneliti mengelompokan peserta didik secara berpasangan. Kemudian peserta didik diminta untuk membagi peran, yaitu sebagai problem solver (pemecah masalah) dan listener (pendengar), serta diberikan pengarahan mengenai tugas dari tiap perannya masing-masing. Diakhir kegiatan pembelajaran siklus I dilaksanakan tes dan diperoleh hasil sebagai berikut.

Tabel 2. Keterangan Nilai Siklus I

\begin{tabular}{lc}
\hline Keterangan & Jumlah \\
\hline Tidak Tuntas & 17 \\
Tuntas & 23 \\
Persentase & $58 \%$ \\
\hline
\end{tabular}

Berdasarkan dari tabel 2 dapat dilihat dari keseluruhan persentase ketuntasan peserta didik adalah 58\% dan kategori kemampuannya cukup. 
Perlu bimbingan agar peserta didik lebih banyak aktif menjawab (penugasan latihan soal dimensi tiga). Harus ada waktu tambahan dalam bertanya dan perlu bimbingan dalam membiasakan dalam memecahkan masalah. Nilai terendah pada siklus ini adalah 25 dan nilai tertinggi 90.

\section{Hasil Penelitian Serta Pembahasan Siklus II}

Untuk siklus kedua proses pembelajarannya sama, diberikan lembar kerja sebanyak 2 soal dengan indikator soal yaitu menentukan jarak garis ke garis bidang dalam ruang, menentukan garis ke bidang dalam ruang dan menentukan jarak bidang ke bidang dalam ruang.

Peserta didik bersama kelompoknya sebanyak 2 orang mendiskusikan penerapan dimensi tiga. Pada siklus ini peserta didik bertukar peran yang semula PS (Problem Solver) menjadi L (Listener) dan L (Listener) menjadi PS (Problem Solver). Diakhir kegiatan pembelajaran siklus II pun dilaksanakan tes dan diperoleh hasil sebagai berikut.

Tabel 3. Keterangan Nilai Siklus II

\begin{tabular}{lc}
\hline Keterangan & Jumlah \\
\hline Tidak Tuntas & 12 \\
Tuntas & 28 \\
Persentase & $70 \%$ \\
\hline
\end{tabular}

Gambaran yang lebih jelasnya mengenai nilai tes hasil belajar peserta didik berdasarkan hasil siklus I, siklus II, dan Ulangan Harian adalah sebagai berikut berikut:

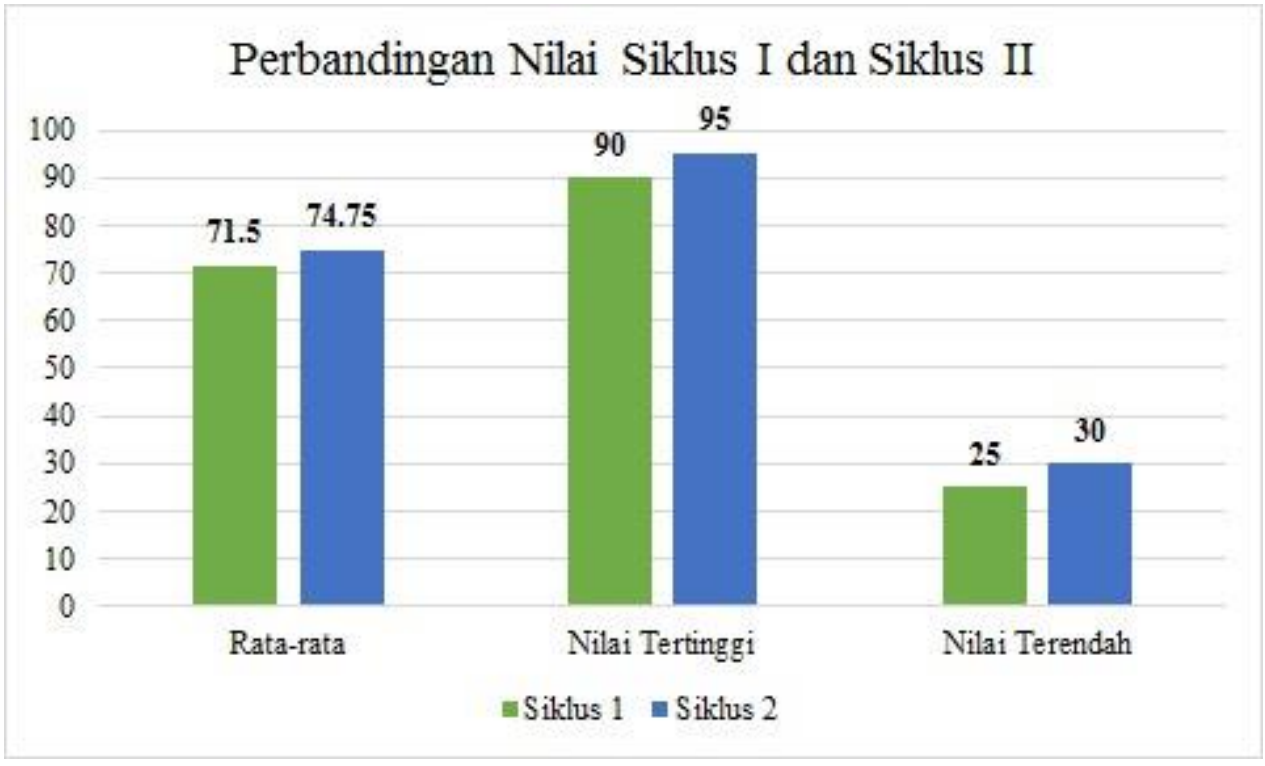

Gambar 1. Diagram Siklus I dan Siklus II 
Berdasarkan dari tabel 3 dan gambar 1 dapat dilihat dari keseluruhan persentase ketuntasan peserta didik adalah $70 \%$ dan kategori kemampuannya baik. Peserta didik sudah aktif dalam memecahkan masalah, perlu bimbingan lebih intensif. Harus ada waktu tambahan dalam bertanya. Metoda pemecahan masalah dapat dilaksanakan dengan lebih baik lagi agar peserta didik dapat memecahkan variasi soal. Nilai terendah meningkat menjadi 30 dan nilai tertinggi meningkat menjadi 95.

\section{Pembahasan Hasil Penelitian Secara Keseluruhan}

Data hasil belajar diperoleh dari tes yang diberikan kepada peserta didik setelah selesai pembelajaran dengan menggunakan metode TAPPS pada siklus 1 dan siklus 2 . Jawaban yang telah diisi oleh peserta didik diberi skor sesuai dengan pedoman penskoran yang telah dibuat peneliti pada setiap tahapan pemecahan masalah yang dilalui peserta didik.

Tabel 4. Keterangan Nilai Hasil Belajar

\begin{tabular}{lc}
\hline Keterangan & Jumlah \\
\hline Tidak Tuntas & 6 \\
Tuntas & 34 \\
Persentase & $85 \%$ \\
\hline
\end{tabular}

Gambaran yang lebih jelasnya mengenai nilai tes hasil belajar peserta didik berdasarkan hasil siklus I, siklus II, dan Ulangan Harian adalah sebagai berikut berikut:

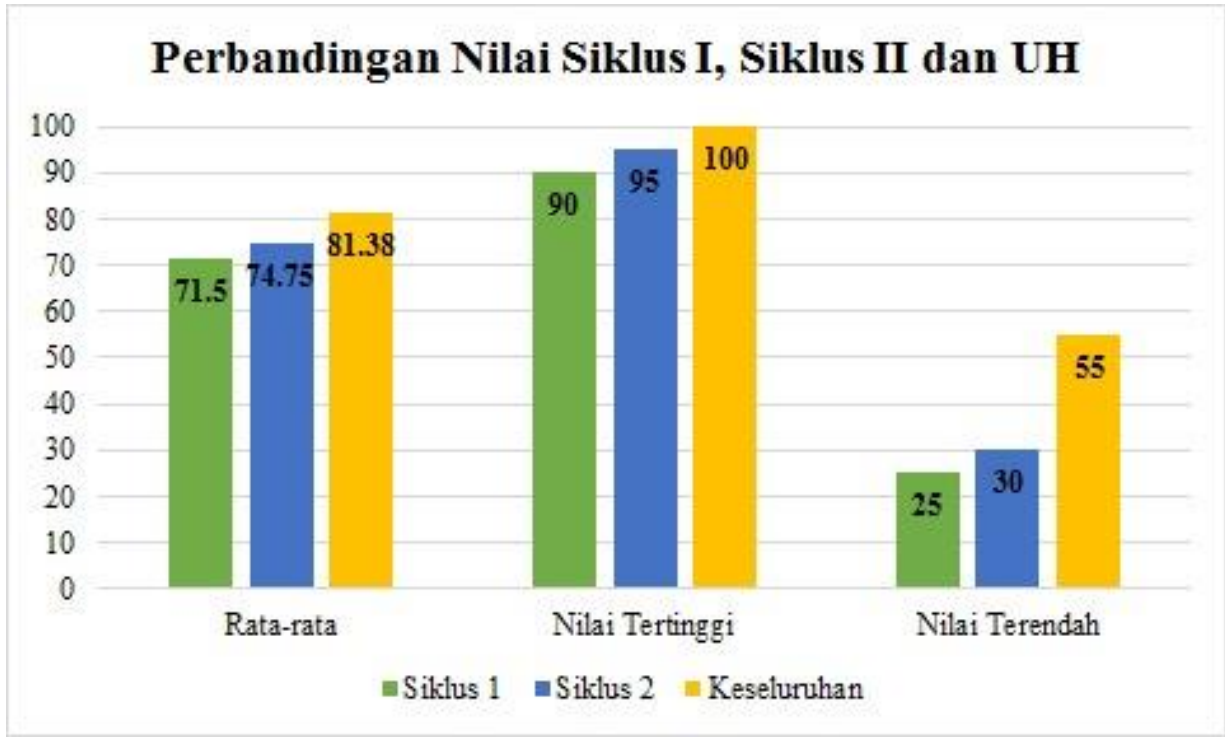

Gambar 2 Diagram Siklus I, Siklus II, dan Ulangan Harian

Bedasarkan data dari tabel 4 dan gambar 2 di atas dapat dilihat bahwa hasil belajar peserta didik mengalami peningkatan. Dan membuktikan bahwa hasil belajar peserta didik 
kelas XII MIPA 1 SMAN 8 Bandung dengan menggunakan TAPPS dikategorikan cukup untuk siklus 1, baik untuk siklus 2 dan sangat baik pada ulangan harian.

\section{KESIMPULAN}

Berdasarkan hasil penelitian dan pembahasan mengenai penerapan metode pembelajaran Thinking Aloud Pair Problem Solving terhadap peningkatan hasil belajar Matematika pada peserta didik kelas XII MIPA 1 SMAN 8 Bandung diperoleh kesimpulan metode tersebut dapat digunakan dan terdapat peningkatan hasil belajar peserta didik kelas XII MIPA 1 SMAN 8 Bandung dengan metode pembelajaran Thinking Aloud Pair Problem Solving.

\section{REKOMENDASI}

Berdasarkan pada penemuan-penemuan peneliti selama melakukan penelitian, maka peneliti memberikan saran-saran untuk guru dan calon guru Matematika; metode pembelajaran Thinking Aloud Pair Problem Solving dapat digunakan sebagai alternatif dalam pembelajaran untuk meningkatkan hasil belajar peserta didik karena melalui peranan yang ada, peserta didik dapat dilatih untuk mengembangkan cara berpikirnya serta cara berpikir orang lain. Untuk peserta didik; metode pembelajaran Thinking Aloud Pair Problem Solving ini dapat meningkatkan kemampuan dalam menyelesaikan masalah matematika yang ada. Peserta didik harus terus berlatih sesuai peranan metode ini agar dapat berpikir lebih baik. Untuk peneliti selanjutnya, waktu yang diperlukan dalam penelitian ini cukup banyak oleh karena itu peneliti diharapkan mempersiapkan seluruh hal yang diperlukan agar menguasai metode pemnbelajaran Thinking Aloud Pair Problem Solving ini dengan baik. Dalam pelaksanaannya guru harus dapat memotivasi peserta didik karena metode pembelajaran ini baru bagi mereka, pada awal pertemuan peserta didik akan merasa kesulitan dalam menentukan masalah dan menjalankan peranannya. Diharapkan untuk peneliti selanjutnya agar metode pembelajaran Thinking Aloud Pair Problem Solving ini dapat diterapkan dalam berbagai pokok bahasan atau bahkan dapat diterapkan dalam berbagai bidang ilmu pendidikan lainnya.

\section{UCAPAN TERIMA KASIH}

Penelitian ini dapat dilaksakan dengan baik berkat bantuan dari berbagai pihak, untuk itu peneliti mengucapkan terimakasih kepada Bapak Suryana, S.Pd. selaku Kepala SMAN 8 Bandung yang telah memberikan izin untuk melakukan penelitian. 


\section{REFERENSI}

Arikunto, S. (2010). Prosedur Penelitian Suatu Pendekatan Praktik. Jakarta : Rineka Cipta

Brousseau, Guy. (2002). Mathematics education library: theory of didactical situations in mathematics. (nineteenth ed). New York, Boston, Dordrecht, London, Moscow: Kluwer Academic Publishers.

Barkley, P. Cross, dan C.H. Major. (2012). Collaborative Learning Techniques. Bandung : Nusa Media

Gagne. (1977). The Condition of Learning. New York : Holt

Janulis, P. Purba. (2012). Pemecahan Masalah dan Penggunaan Strategi Pemecahan Masalah. Artikel P.J. Purba

Stice, J. E. (1987). Teaching Problem Solving. [Online]. Tersedia : http//wwwcsi.unian.it.educa/problemsolving/stice-ps.html

Sugiyono. 2012. Metode Penelitian Pendidikan. Bandung : Alfabeta 